\title{
APPENDIX B: ADDITIONAL READINGS
}

1. The World Bank. (January 2011). Guidelines Procurement of goods, works and non-consulting services under IBRD loans and IDA credits by World Bank borrowers. Washington, DC: The World Bank.

2. The World Bank. (January 2011). Guidelines Selection and employment of consultants under IBRD credits \& grants by World Bank Borrowers. Washington, DC: The World Bank.

3. UNCITRAL. (2011). Model law on public procurement: Vienna: UNCITRAL.

4. OECD. (January 2010). Methodology for assessing procurement systems (MAPS). Paris: OECD.

5. World Bank Institute. (2012). Procurement innovation challenge. Washington, DC: The World Bank.

6. OECD. (January 2011). Economic issues in public procurement. Paris: OECD.

7. EBRD. (2010). Strengthening public procurement. London: EBRD.

8. OECD. (2000). Centralized and decentralized public procurement. Paris: OECD. 
9. OECD. (January 2011). What are the public procurement procedures and when can they be used? Paris: OECD.

10. The World Bank \& DfID. (August 2010). Linking procurement and political economy. Washington, DC and London: World Bank and DfID.

11. Office of Fair Trading. (September 2004). Assessing the impact of public sector procurement on competition. London: OFT.

12. UNDP. (October 2010). Public procurement capacity building guide. New York, NY: UNDP.

13. The World Bank. (n.d.). Fraud and corruption handbook. Washington, DC: The World Bank.

14. OECD. (November 2007). How to fight corruption effectively in public procurement. Paris: OECD.

15. The World Bank, ADB, IAB. (n.d.). Electronic government procurement roadmap.

16. European Commission. (2004). Buying green! A handbook on environmental public procurement. Brussels: European Commission.

17. OECD. (August 2011). Public procurement Concessions and PPPs. Paris: OECD. 